technological information on the use of environmental modification techniques for peaceful purposes.

The Conference further calls upon States Parties also to provide and facilitate the fullest possible exchange of scientific and technological information on the research on, and the development of, such environmental modificaiton techniques. Furthermore, and in order to ensure the widest possible exchange of such information, the Conference invites the Secretary-General of the United Nations to receive such information for dissemination. For this purpose, the Conference requests the Secretary-General to utilize to the maximum extent the United Nations agencies with competence in environmental topics.

The Conference also calls upon States Parties in a position to do so, to continue to contribute to and strengthen, alone or together with other States or international organizations, international economic and scientific cooperation in the preservation, improvement, and peaceful utilization, of the environment, with due consideration for the needs of the developing areas of the world.

\section{Article IV}

The Conference notes the provisions of Article IV, which requires each State Party to take any measures it considers necessary in accordance with its constitutional processes, to prohibit and prevent any activity in violation of the provisions of the Convention anywhere under its jurisdiction or control, and invites States Parties which have found it necessary to enact specific legislation, or take other regulatory measures relevant to this Article, to make available the appropriate texts to the United Nations Department of Disarmament Affairs, for the purposes of consultation.

\section{Article $V$}

The Conference notes with satisfaction that no State Party has found it necessary to invoke the provisions of Article $\mathrm{V}$ dealing with international complaints and verification procedures. The Conference reaffirms the importance of paragraph I of this Article, which contains the undertaking of States Parties to consult one another and to cooperate in solving any problems which may arise in relation to the objectives of, or in the application of the provisions of, the Convention, and of paragraph 2 , which provides for the convening of a Consultative Committee of Experts. In the view of the Conference the provisions of Article V, paragraphs 1 and 2, do not exclude the possibility of consideration, by States Parties, of the summary of findings of fact of the Consultative Committee of Experts.

The Conference also notes the importance of Article V paragraphs 3 and 4, which, in addition to the procedures contained in Article V paragraphs 1 and 2, provide that any State Party which finds that any other State Party is acting in breach of its obligations under the Convention, may lodge a complaint with the United Nations Security Council, and under which each State Party undertakes to coop- erate in carrying out any investigation which the Security Council may initiate.

The Conference considers that the flexibility of the provisions concerning consultation and cooperation on any problems which may arise in relation to the Convention, or in the application of the provisions of the Convention, should enable complaints or disputes to be effectively resolved.

\section{Article VI}

The Conference notes that during the operating of the Convention, no State Party has proposed any amendments to this Convention under the procedures laid down in this Article.

\section{Article VII}

The Conference reaffirms that the Convention should be of unlimited duration.

\section{Article VIII}

The Conference notes with satisfaction the spirit of cooperation in which the Review Conference was held. The Conference, recognizing the importance of the review mechanism provided in Article VIII, decides that a second Review Conference may be held in Geneva at the request of a majority of States Parties not earlier than 1989. If no Review Conference is held before 1994, the Depositary is requested to solicit the views of all States Parties concerning the convening of such a Conference in accordance with Article VIII paragraph 3 of the Convention.

\section{Article IX}

The Conference stresses that the six years which have elapsed since the date of entry into force of the Convention, have demonstrated its effectiveness.

The Conference notes that 45 States have become Parties to the Convention and a further 19 States have signed but have yet to ratify the Convention. The Conference notes with concern that the Convention has not yet achieved universal acceptance. Therefore the Conference calls upon all signatory States which have not ratified the Convention to do so without delay, and upon those States which have not signed the Convention to adhere to it as soon as possible and thereby join the States Parties thereto in their efforts to prohibit effectively military or any other hostile use of environmental modification tecnhiques. Such adherence would be a significant contribution to international confidence and to the strengthening of trust amongst nations.

INFORMATION SERVICE

United Nations Office at Geneva Palais des Nations

1211 Geneva 10

Switzerland.

\title{
The Huge Bird-cliff, Látrabjarg, in Western Iceland*
}

Bird-cliffs are fascinating places in more ways than one. Thus they often form the most spectacular stretches of rugged and exposed coasts, while the large numbers of noisy and conspicuous birds inhabiting them seldom fail to

* The main text was circulated unedited in mimeographed form by the European Information Centre for Nature Conservation, Council of Europe, B.P. 431 R6, 67006 Strasbourg, France, to whom our gratitude is due for this and other notable 'Environment Features'.-Ed. impress the observer. At the higher latitudes there is, in addition, the sharp contrast between a bleak hinterland and the teeming life of the bird-cliff. ${ }^{\dagger}$

One such place is Látrabjarg, on the westernmost tip of Iceland. The size of this cliff is such that it is difficult to

${ }^{\dagger}$ See, for example, our The Isle of Auks (Edward Arnold, London, England, UK: 253 pp., illustr. 1932) and 'The Vegetation of Akpatok Island, Part II' (Journal of Ecology, XXIII, pp. 161-209, figs and photos, 1935).-Ed. 
appreciate, even when one is watching from its edge or from a boat below it. In the breeding season there are birds seemingly everywhere-on the cliff, on the sea, and in the air. An almost unbroken succession of flocks flies continuously to and from distant fishing-grounds. The birds take advantage of the wind by flying high on a tail-wind, and they are forced to fly low against a head-wind. This leads to an organized mode of traffic, resembling a divided highway or a conveyor belt. The continuous din of birds' voices, and the strong fishy odour of bird droppings, contribute to a feeling of being in a strange city. In the surf below Grey Seals (Halichoerus grypus) roll, and are often seen feeding on some of the big fishes that frequent the rocky bottom. Further out, whales of several species can sometimes be seen passing.

Numerous seabird colonies are found all around the coasts of Iceland, especially on headlands and islands. The largest colonies are found on three huge sea-cliffs on the north-west peninsula; these include Látrabjarg and the slightly smaller Hornbjarg and Haelavikurbjarg. Other very large colonies include those of the Westmann Islands off the south coast and Grimsey off the north coast.

Látrabjarg is an enormous cliff. It is about $14 \mathrm{~km}$ long and the average height is about $250 \mathrm{~m}$ above sea-level, the highest point of the cliff being $441 \mathrm{~m}$. The total area of cliff-face is about 350 hectares. Látrabjarg is made up of the remaining half of a mountain which has been cut up by the pounding of sea waves, exposing layers of basaltic lavafields which flowed during the Tertiary.

\section{Birds' Nesting}

The cliff faces south, towards the wide bay of Breidafjördur, which on the opposite side is bordered by a hilly promontory crowned at its outer end by the fine volcanic cone of Snaefellsjökull. About half of the cliff, mainly the westernmost part and most of the lower reaches, is a sheer precipice practically without vegetation, whereas the upper and more eastern parts are less steep and covered with lush herbaceous vegetation. In several places below the cliff, rockfalls have formed screes.

Ten species of seabirds breed on the cliff. Most can be found over wide stretches, and typically any one spot will have a mixture of species. There are, however, subtle differences: the Common Guillemot (Uria aalge) is mostly found on broad ledges, whereas the closely-related Brünnich's Guillemot ( $U$. lomvia) frequents narrow ledges and sloping rock-faces, often with much loose material. Kittiwakes (Rissa tridactyla) build their nests on tiny ledges on the steepest part of the cliff. Razorbills (Alca torda) occupy narrow cracks in the rock, especially between layers of lava, as well as boulder areas. At the foot of the cliff a few Shags (Phalacrocorax aristotelis) and Black Guillemots (Cepphus grylle) share the boulders with the Razorbills. Vegetated parts of the cliff are occupied mainly by Puffins (Fratercula arctica), which make their nest-burrows in the soil, and Fulmars (Fulmarus glacialis), together with a few Glaucous Gulls (Larus hyperboreus) and an occasional Greater Black-backed Gull (L. marinus).

Some land-birds also nest on the cliff, including the Raven (Corvus corax), Wren (Troglodytes troglodytes), White Wagtail (Motacilla alba), and Snow Bunting (Plectrophenax nivalis).

\section{- and Feeding}

The seabirds of Látrabjarg feed in some very rich fishinggrounds. An area of major upwelling and much vertical mixing of cold nutrient-rich polar water and warm Atlantic water is found some 100 nautical miles $(185 \mathrm{~km})$ offshore. Inshore areas are also very rich, though much remains to be learned about the feeding of the Latrabjarg birds and their role in the local marine ecosystems. Small crustaceans, including species of krill and shrimps, and and eels, appear to be the main food of most species.

The three large auks - the Common and Brünnich's Guillemots and the Razorbill-all feed mainly to the north of the peninsula of which Latrabjarg forms the south shore. This means that the birds (which avoid flying over land) have to turn a corner on their feeding trips, and thus traffic is concentrated at the tip of the peninsula. By estimating the numbers passing as well as the rate of travel by individual birds and the proportions of different species, we can estimate the numbers of these three species at Latrabjarg. As it turns out, an average of 700 auks per minute pass by in each direction, varying from a few dozen around midnight to peaks of about 3,000 in the early morning or evening.

Recent estimates suggest that about 400,000 pairs of Common Guillemot, perhaps slightly fewer of Razorbill, and about 250,000 of Brünich's Guillemot, breed at Látrabjarg. These figures suggest that as many as twothirds of the world population of Razorbill breed on Latrabjarg, as well as very important proportions of the Atlantic populations of the two guillemots. The number of Puffins at Látrabjarg may also be in the hundreds of thousands, and there are certainly well over 100,000 pairs of Fulmar on the cliff, and probably some tens of thousands of Kittiwakes. Other species only nest in small numbers.

\section{Predators}

A number of predators and scavengers make their living on the cliff. The upper edges and slopes are frequented by the Arctic Fox (Alopex lagopus), which is a surprisingly successful hunter in these conditions of veritable brinkmanship. Avian predators are mainly Ravens, including breeding pairs and a large flock of non-breeders, and the gulls. Arctic Skuas (Stercorarius parasiticus) are also common, and specialize in robbing food off auks and Kittiwakes on their way home from fishing. Yet predator numbers are few in comparison with the millions of seabirds breeding on Látrabjarg, and it must be concluded that the impact of predators on these populations is insignificant.

Man has been a major predator of the birds of Látrabjarg ever since Iceland was first settled by humans some 1,100 years ago. Until quite recently the eggs of all species were taken as well as fully-grown nestlings of Puffin, Kittiwake, and adult guillemots. Nowadays exploitation has dwindled, although some 'egging' still goes on in the spring. As in other places where large concentrations of breeding seabirds occur, local and often highly refined ways of exploiting the cliff had been developed at Látrabjarg. Men were lowered over the cliff on ropes and they landed below it and climbed from below. The timing of taking eggs and birds of each species had to be carefully adjusted, and ways of moving about on the cliff were practised from a very early age. Even if the effort was large, it seems that the impact of Man on the cliff birds was small. For instance, in 1883 a total of 36,000 adult guillemots were reported to have been killed at Latrabjarg. This was considered a record catch, but it is only about $5 \%$ of the present population of Common Guillemot on the cliff. Perhaps Man was always a rather inefficient predator at Látrabjarg, like the natural predators, the numbers taken being influenced by other resources rather than by the seasonal superabundance of cliff-birds.

Arnthór Gardarsson, Professor of Zoology Institute of Biology

University of Iceland

Grensásvegur 12

ISL-108 Revkjavik

Iceland. 